\title{
TWO UNCOLLECTED EARLY REVIEWS OF THE 1855 AND 1856 EDITIONS OF LEAVES OF GRASS
}

\author{
Kenneth M. Price and Charles B. Green
}

TwO PREVIOUSLY UNRECORDED early reviews of Leaves of Grass help further illuminate Whitman's initial reception. The first, treating the 1855 edition, is part of an anonymous essay review by George Eliot, "Art and Belles Lettres," that appeared in the Westminster and Foreign Quarterly Review (April 1856). ${ }^{1}$ The second, treating the 1856 edition, appeared in the Harvard Magazine (January 1857), a publication founded three years earlier by Harvard students. ${ }^{2}$ These uncollected reviews supplement Kenneth M. Price's Walt Whitman: The Contemporary Reviews and will be incorporated in the Walt Whitman Hypertext Archive. ${ }^{3}$

In "Art and Belles Lettres" Eliot provided extended criticism on everything from a volume of John Ruskin's Modern Painters and Adolf Stahr's study of Greek sculpture to a collection of tales by Wilkie Collins and a translation of Homer's Iliad, yet she limited her commentary on Whitman to two sentences at the very end of her essay:

We have still said nothing . . . of another American production which, according to some Transatlantic critics, is to initiate a new school of poetry. This is a poem called "Leaves of Grass," and, instead of criticizing it, we will give a short extract, typical in every respect, except that it contains none of the very bold expressions by which the author indicates his contempt for the "prejudices" of decency.

She then quoted lines 90-101 of the 1855 Leaves, beginning "A child said, What is the grass?" and, immediately afterward, quoted lines 684691 beginning "I think I could turn and live with the animals . . . they are so placid and self-contained."

In this review and elsewhere Eliot expressed interest in the poet even as she shied away from fully endorsing his work. She acknowledged Whitman's challenge to conventional morality without making explicit her own attitude toward that challenge. (It seems probable that she shared Whitman's impatience with what he called "blurt" about virtue and vice since she had recently defied Victorian mores herself). ${ }^{4}$ Eliot neither supported nor rejected the claim made by some American critics that Whitman had launched a new poetic movement. Her am- 
bivalence continued later in her career when she invoked Whitman in Daniel Deronda, using two lines from "Vocalism" as an epigraph ("Surely whoever speaks to me in the right voice, him or her I shall follow, / As the water follows the moon, silently with fluid steps anywhere around the globe"), only to wish later that she had expunged the quotation, fearing that it "might be taken as the sign of a special admiration." Gordon Haight has argued that Eliot's second thoughts about the motto sprang from an attack on Whitman in the Saturday Review, which declared that "although there is a small coterie of persons in this country who are not ashamed to confess their liking for Whitman's nastiness, his own countrymen have universally repudiated him." 6

The review of the second edition of Leaves of Grass appearing in The Harvard Magazine also raised questions of sexuality and decency:

\section{Leaves of Grass. Second edition. Brooklyn, N.Y. 1856. 16mo. Pp. 384.}

There is something wholesome, fresh, invigorating, in this book, and we like it. Now that almost every one has passed his gibe on it-that the same sapient critics have called its author idiot, sensualist, madman, - that the outraged Cautious Elderly maiden of cerulean stock has held up her finger and cried, "O fie!"-we acknowledge our partiality very diffidently. Yet we left our "good clothes" in town, and we will roll in the jolly, long Timothy, in spite of the crabbed farmer who just holloed, "Come out of that grass!" It is good, because it is a true thing; freely sprouting right and left, not closely mowed like most of the very proper lawn plots that meet with approval. It is good because it shows that the American mind does not become callous, with all its closeness of attention to, and skill in, type-cases, jack-planes, and sledge-hammers; that the vigor and life of the "roughs" who fight our battles, break in our wild country, yell around the ballot-box, and cheer or hiss as they please, is by no means dead. It is good because it reminds us that education is only an instrument, after all, often overvalued, - a fact liberally educated men practically forget in their contemptuous reception of any native outbursts of genius. Not to sneer at education at all, it is wholesome to have the "mortar-board" knocked over the collegiate eyes occasionally. Somebody says Walt Whitman is a gesticulating satyr, and don't see anything here but rank witch-grass, fit for the furnace. The book is of "healthy" tone and expression sometimes, but where is the harm? Is it squeamishness or something worse that, in our day, kicks our plain-spoken friend out doors, and has not a word against smooth-spoken vice in broadcloth, which doesn't shock us with plain words? Influence is of no account; but a few objectionable phrases ought to burn a book. Strip off the rag!

Jaunty and irreverent, this reviewer displays a shrewd awareness of contemporary issues and of the discourse surrounding Leaves of Grass. He belittles the notion that Leaves of Grass ought to be thrown instantly in the fire, as advocated by the March 15, 1856, Saturday Review. Moreover, when this reviewer notes that Whitman has been called a "gesticulating satyr," he sets himself at odds with the New York Times and the Christian Examiner. The Times had described Whitman as being like a "drunken satyr" roaming through "every field of lascivious thought . . . with a seemingly exhaustless prurient pleasure." And the Christian Examiner asserted that "it is especially desirable to be able to discern the difference between the nudity of a statue and the gestures of a satyr." 
When Bronson Alcott visited Whitman, he, too, had satyrs on the brain. Alcott's journal for October 4, 1856, records that Whitman was "Bacchus-browed, bearded like a satyr, and rank." A month later, November 10, 1856, Alcott noted that "A few books were piled disorderly over the mantel-piece, and some characteristic pictures-a Hercules, a Bacchus, and a satyr-were pasted, unframed, upon the rude walls." 8

Perhaps there was a picture of a satyr on the poet's bedroom wall in Brooklyn, but if so it constituted a rare expression of Whitman's interest in this mythological figure. He never used the word "satyr" in Leaves of Grass nor in his collected prose. ${ }^{9}$ For others, however, satyrs offered a readily available cultural lens through which they could see (in refracted fashion) Whitman. Satyrs offered not only a way of imagining a certain type of aggressive sexuality but also a means of conceptualizing the limits of the human. The first line of the New York Times review of Leaves of Grass (1856) asked: "What Centaur have we here, half man, half beast, neighing shrill defiance to all the world?" Alcott and these reviewers all have in common a fascination with the chain of being. If transcendentalists were intrigued by the prospect of human perfection and the possibility of reaching a border land where the human might brush with the divine, they were equally fascinated by the liminal space linking the human and the animal.

With remarkable frequency reviewers questioned Whitman's basic humanity. The same impulse that led several early commentators to link Whitman with satyrs led a reviewer in the London Critic to liken him to Caliban, the half-human slave of Prospero, son of the witch Sycorax and a devil, and symbol of base and lustful urges. ${ }^{10}$ Of course Whitman's texts invited such conclusions since they put definitions of humanity at issue, especially in the first two editions. The speaker blurred identities, taking on the role of the savage (etymologically, a sylvan creature and thus like a faun) and becoming the hounded slave, both figures commonly understood to be, at best, on the bottom rung of the ladder of humanity. Leaves of Grass repeatedly throws established hierarchies into question, never so powerfully as when it exposes dominant habits of thought that rendered some people more human than others:

The friendly and flowing savage ... Who is he?

Is he waiting for civilization or past it and mastering it?

These newly identified reviews deepen our understanding of Whitman's initial reception. They should be of value to those interested in how Whitman's work was first received in England, in how women initially responded to Leaves of Grass, and in how Whitman-often inclined to hold schools in abeyance-was received at Harvard, an institution starting its long history of important commentary on the poet. These two reviews also clarify that, for several early readers of Leaves of 
Grass, Whitman's famous question- "Who goes there! hankering, gross, mystical, nude?"-should perhaps have been recast as "What goes there ... ?"

University of Nebraska, Lincoln

University of Oklahoma

\section{NOTES}

1 "Art and Belles Lettres" appeared in the London edition of The Westminster and Foreign Quarterly Review n.s. 9 (April 1, 1856), 625-650. The comments on Whitman are on the final page of this article. The essay is reprinted in Westminster Review (American Edition) 42, no. 2 (April 1856), 343-356. The review by Eliot, though unrecorded in Whitman bibliographies and collections, has been noted by Eliot scholars; see, for example, Gordon S. Haight, George Eliot: A Biography (New York: Oxford University Press, 1968), 184.

2 The Harvard Magazine 3 (January 1857), 40-41. One of the founders of the Harvard Magazine was Frank Sanborn (Harvard 1855) who later became a good friend of Whitman and hosted the poet at his home in Concord in 1881.

3 Walt Whitman: The Contemporary Reviezss (New York: Cambridge University Press, 1996) and The Walt Whitman Hypertext Archive, ed. Kenneth M. Price and Ed Folsom $<$ http://jefferson.village.virginia.edu/whitman/>.

4 When Eliot traveled to Weimar with George Henry Lewes in 1854, she made it clear that she had joined her life with his. It was a union they both regarded as a marriage. Lewes, however, had been unable to gain a divorce from his first wife because he was said to have condoned her infidelity by raising her children by another man as his own.

5 Eliot reported in a letter to John Blackwood of April 18, 1876: "We are rather vexed, now it is too late, that I did not carry out a sort of incipient intention to expunge a motto from Walt Whitman which I inserted in Book IV. Of course the whole is irrevocable by this time, but I should have otherwise thought it worth while to have a new page, not because the motto itself is objectionable to me-it was one of the finer things which had clung to me from among his writings - but because, since I quote so few poets, my selection of a motto from Walt Whitman might be taken as the sign of a special admiration which I am very far from feeling. How imperfectly one's mind acts in proof reading! Mr. Lewes had taken up Book IV yesterday to re-read it for his pleasure merely, and though he had read it several times before, he never till yesterday made a remark against taking a motto from Walt Whitman. I, again, had continually had an 'appetency' towards removing the motto and had never carried it out - perhaps from that sort of flaccidity which comes over me about what has been done, when I am occupied with what is being done." See The George Eliot Letters, ed. Gordon S. Haight (New Haven: Yale University Press, 1955), 6:241. Interestingly George Henry Lewes records a $£ 2$ gift for Whitman under "Charities."

6 Saturday Review (March 18, 1876), 360-361. For Haight's comment, see Eliot's Letters, 6:241n. Harold Blodgett's Walt Whitman in England (Ithaca: Cornell University Press, 1934), 169-171, provides a good overview of Whitman's and Eliot's opinions of one another. 
7 One additional reviewer associated Whitman with satyrs. The Spectator 33 (14 July 1860), 669-670, remarked about the 1860 edition that the "figures of Priapus and the Satyrs should have adorned the covers" (rpt. in Walt Whitman: The Contemporary Reviews, 100).

8 Critical Essays on Walt Whitman, ed. James Woodress (Boston: G. K. Hall, 1983), 38. Henry David Thoreau accompanied Alcott on his November 1856 visit to Whitman. Interestingly, Thoreau concluded that Whitman was "essentially a gentleman," as he remarked in a letter to H. G. O. Blake. After reading the 1856 Leaves of Grass, which Whitman gave him, Thoreau, in another letter to Blake, noted that " 2 or 3 pieces in the book are simply sensual," adding, "It is as if the beasts spoke." Significantly, though, Thoreau did not adopt the trope of the satyr, perhaps because he went on to emphasize the ennobling, spiritual qualities of Whitman and his book: "He occasionally suggests something a little more than human." See The Correspondence of Henry David Thoreau, ed. Walter Harding and Carl Bode (New York: New York University Press, 1958), 441 and 444-445.

9 Writing somewhat later, Edward Dowden, in another review, was perceptive about the oddity of associating Whitman with satyrs: "For [Whitman's] imagination the powers of the earth do not incarnate themselves in the forms of god and demigod, faun and satyr, oread, dryad, and nymph. . . But the great Mother-the Earth-is one in character with her children of the democracy, who, at last, as the poet holds, have learned to live and work in her great style. She is tolerant, includes diversity, refuses nothing, shuts no one out; she is powerful, full of vitality, generous, proud, perfect in natural rectitude, does not discuss her duty to God, never apologizes, does not argue, is incomprehensible, silent, coarse, productive, charitable, rich in the organs and instincts of sex, and at the same time continent and chaste" (Westminster Review 96 [July 1871], 63; rpt. in Walt Whitman: The Contemporary Reviews, 204).

10 Critic [London] 15 (April 1, 1856), 170-171. Rpt. in Walt Whitman: The Contemporary Reviews, 44. The link between slaves and half-human satyrs or fauns (Greek and Roman names for the same sylvan deity) is made explicit in Nathaniel Hawthorne's "Chiefly About War Matters." Hawthorne presents "one very pregnant token of a social system thoroughly disturbed," a token that involves a party of escaped slaves fleeing Virginia for Washington, D.C.: "So rudely were they attired-as if their garb had grown upon them spontaneously-and so picturesquely natural in their manners, and wearing such a crust of primeval simplicity (which is quite polished away from the northern black man,) that they seemed a kind of creature by themselves, not altogether human, but perhaps quite as good, and akin to the fauns and rustic deities of olden times. ... For the sake of the manhood which is latent in them, I would not have turned them back, but I should have felt almost as reluctant, on their own account, to hasten them forward to the stranger's land" (Hawthorne, Miscellaneous Prose and Verse, ed. Thomas Woodson, Claude M. Simpson, and L. Neal Smith [Columbus: Ohio State University Press, 1994], 419-420). Hawthorne's fascination with the figure of the faun is most fully on display in The Marble Faun. An equally interesting conjunction of the issues of race, satyrs, and power relations is found in Melville's Benito Cereno (1855): the stern piece of the San Dominick was "medallioned about by groups of mythological or symbolical devices; uppermost and central of which was a dark satyr in a mask, holding his foot on the prostrate neck of a writhing figure, likewise masked." See The Piazza Tales and Other Prose Pieces, 1839-1860, ed. Harrison Hayford, Alma A. MacDougall, and G. Thomas Tanselle (Northwestern University Press and the Newberry Library, 1987), 49. 